\title{
Response of Tomato Plant to Compost Application and Inoculation with Mycorrhizal Fungi Under Salt Stress Conditions
}

\author{
Altome, M.M. Maher G.Nessim. Magda A. Hussein and I. I. Abou el seoud \\ **Soil and Agriculture Chemistry Department, Faculty of Agriculture (Saba Basha), Alex. \\ University
}

\begin{abstract}
Pot experiments using calcareous soil, were carried out to study the influence of irrigation with diluted seawater on tomato (Strain B) plants growth as affected by compost application and mycorrhhiza inoculation during summer 2011 season. Four different irrigation water salinity levels $(0.44,2.70,6.20,12.50 \mathrm{dS} / \mathrm{m})$, three different mycorrhizal treatments (control, Glomus macrocarpium, Glomus intraradices) and three compost rates $(0,20,40 \mathrm{~g} / \mathrm{kg}$ soil) were used. Dry matter production in shoots of tomato plants was significantly decreased by increasing water salinity. Tomato plants were, adversely, affected only by high water salinity levels $(6.20,12.50$ $\mathrm{dS} / \mathrm{m}$ ). However, a substantial increase in shoot dry weight of tomato plant of salt stressed tomato was observed with the compost application and arbuscular mycorrhiza fungi (AMF) inoculation. The $\mathrm{N}$ and $\mathrm{P}$ contents in shoot tomato plants were significantly increased as salinity increased from 0.44 to $6.20 \mathrm{dS} / \mathrm{m}$. Sodium ion content was significantly increased with increasing the salinity of irrigation water from 0.44 to $12.5 \mathrm{dS} / \mathrm{m}$. On another hand, $\mathrm{K}$ content decreased with increasing water salinity. Sodium reduced the contents and uptake of potassium due to ion antagonism. The enhancement in $\mathrm{Mn}, \mathrm{Zn}, \mathrm{Cu}$, and $\mathrm{Fe}$ acquisition or increasing of shoot, dry wehight due to AMF inoculation was more pronounced with Glomus macrocarpium than Glomus intraradiaces under saline conditions. This is further confirmation that compost application and mycorrhizal inoculation are beneficial for tomato plant grown under adverse conditions such as salinity stress.
\end{abstract}

Key words: Mycorrhiza fungi , compost, salinity water, irrigation water, calcareous soil

\section{INTRODUCTION}

Tomato (Lycopersicon esculentum L.) is considered a major vegetable crop in many parts of the world and mostly grown under irrigation, both in protected and open field conditions (Al-Karaki, 2006). Tomato is a moderately sensitive to salinity. It is necessary to conduct the extensive research on growth conditions under moderate salinity to produce vegetative growth.

Nevertheless, salinization of soil is a serious problem and is increasing steadily in many parts of the world, particularly in arid and semi-arid areas. At present, out of 1.5 billion hectares (ha) of cultivated land around the world, about 77 million ha $(5 \%)$ is affected by excess salt content (Sheng et al., 2008). Salt accumulates in soil predominantly as a result of strong winds, high temperatures that cause rates of evaporation to exceed precipitation near coastal areas, utilization of salt-rich industrial wastewater for irrigation, over-pumping of groundwater, excessive use of chemical fertilizers and intensive crop production (Singh et al., 2011).

The effect of salinity on plant growth has been salt studies in different tomato cultivars. Salinity adversely affected the vegetative growth of tomato (Adler and Wilcor, 1987). It had also been reported that high salinity reduces the fresh and dry weights of shoots and roots of tomato plants (Omar et al., 1982). Incorporating or applying factors that enable plants to better withstand salt stress could help improve crop production under saline conditions. 
Arbuscular mycorhizal fungi (AMF) widely occur in saline soils (Aliasgharzadeh et al., 2001). Salinity negatively affects the formation and function of mycorrhiazl symbiosis (Juniper and Bott, 1993). The root colonization by AMF involves a series of morphphysiological and biochemical events that are regulated as well as by environmental factors. The improving salt tolerance of arbuscularmycorhizall-inoculated plants, are still unclear, although, the improved nutrition uptake may be one of the reasons (Poss et al., 1985). In recent years, some studies have indicated that AMF can enhance the plant growth and uptake of nutrients, decrease yield losses of tomato under saline conditions and improved salt tolerance of tomato (Abdel Latef and Chaoxing, 2011). The use of organic composts in agricultural areas is increasing because these improve soil health and nutrient status (Pandey and Shukla, 2006). Varindepal et al., (2006) reported that, incorporation of organic compost decreased $\mathrm{P}$ adsorption, maximum buffering capacity, bonding energy, and increased $P$ concentration in solution. Herencia et al. (2007) demonstrated that long-term use of organic compost in greenhouse soil improved soil fertility, the use of organic fertilizer resulted in higher soil organic matter, soil N content, and available P and K. Kavvadias et al. (2011) reported that organic matter application to soil can resulted in some beneficial soil chemical and physical characteristics, such as increases in organic matter, organic carbon, major nutrients (e.g N, K), water-holding capacity and porosity. Hence, this study was conducted to determine if inoculation of seedling with endo mycorrhiza (VAM) fungi and amendement with compost alleviates soil salinity stress on growth and mineral acquisition of tomato cultivar.

\section{MATERIALS AND METHODS}

Surface calcareous soil sample $(0-15 \mathrm{~cm})$ was taken from El-Zohoor village (Banger El-Sokhar) which is a new reclaimed soil. The sample was air-dried, ground to pass through $2 \mathrm{~mm}$ sieve and thoroughly mixed before using. The characteristics of this soil are presented in Table1. The methods used for soil analysis were those described by Page et al. (1982).

The used compost sample is representative of the compost produced in Egypt, and it was analyzed according to method outlined by Page et al. (1982). The chemical and physical properties of the compost are presented in Table 2.

Four different saline irrigation water $(0.44,2.7,6.2$ and $12.5 \mathrm{dS} / \mathrm{m})$ were prepared by dilution of the sea water using distilled water. The chemical properties of the used saline irrigation water are presented in Table 3. Tap water was used as the control $(0.44 \mathrm{dS} / \mathrm{m})$.

Two arbuscular-mycorrhizal (AM) species belonging to the genus Glomus were used in this study. These species were Glomus macrocarpium and Glomus intraradiaces. The first species was obtained from Department of Plant Nutrition at Göttingen-University Germany and the second one was supplied from Department of Plant Pathology at Hanover University in Germany. The spores of mycorrhizae Glomus spp (mixed) was isolated from the soil by wet sieving and decanting method as described by Gerdemann and Nicolson (1963). 
Table (1). Some initial soil physical and chemical characteristics of the experimental soil

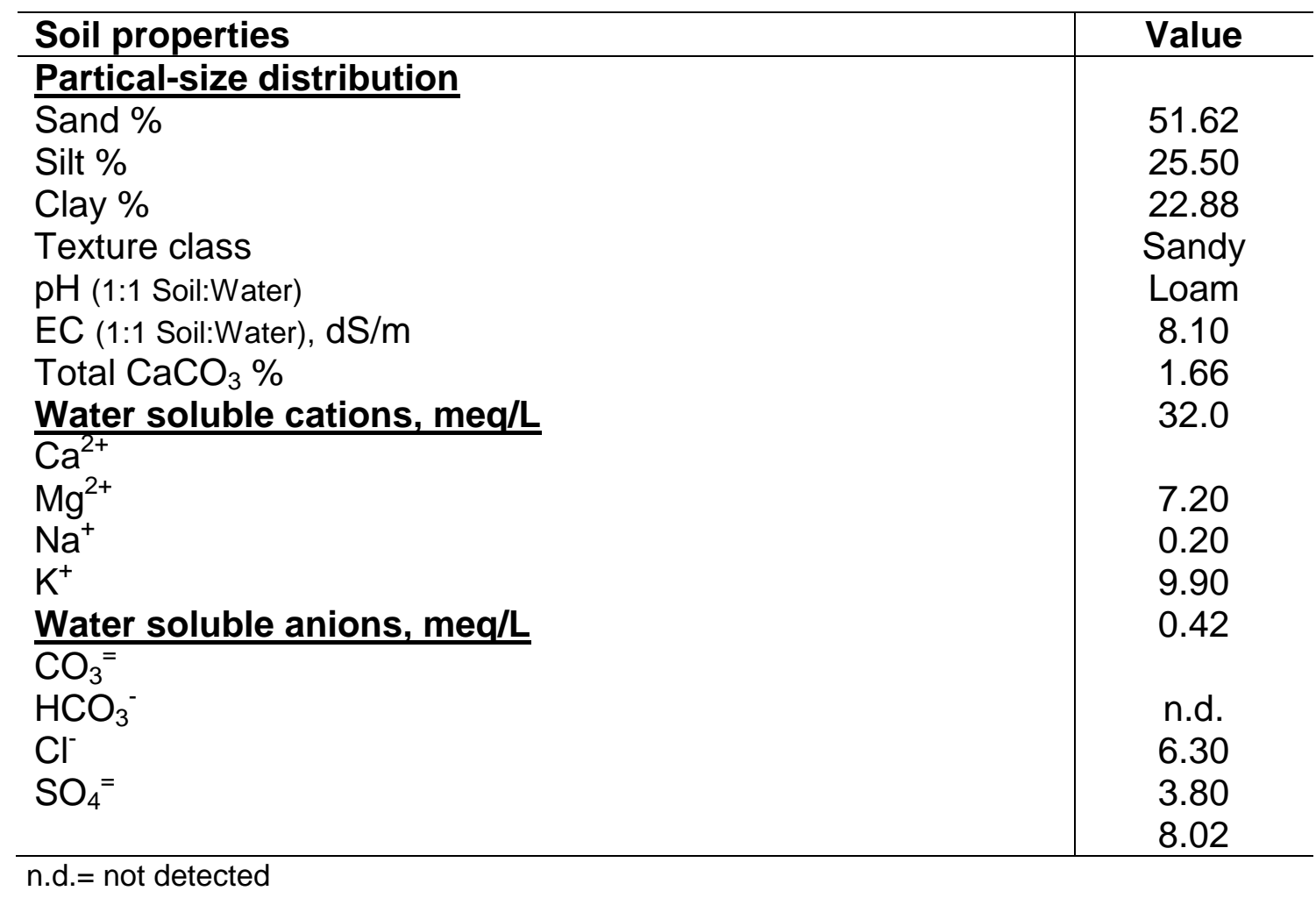

Table (2). Chemical analysis of the compost sample

\begin{tabular}{l|c}
\hline Characters & Value \\
\hline $\mathrm{pH}(1: 2)$ & 7.02 \\
$\mathrm{EC}(1: 2), \mathrm{dS} / \mathrm{m}$ & 4.10 \\
$\mathrm{O} . \mathrm{M}, \%$ & 52.80 \\
Total P,\% & 0.44 \\
Total N, \% & 0.92 \\
Water soluble cations, meq/L & \\
\hline $\mathrm{Ca}^{2+}$ & 18.20 \\
$\mathrm{Mg}^{2+}$ & 9.80 \\
$\mathrm{Na}^{+}$ & 6.50 \\
$\mathrm{~K}^{+}$ & 2.30 \\
Water soluble anions, meq/L $^{-}$ & \\
$\mathrm{HCO}_{3}^{-}$ & 10.20 \\
$\mathrm{Cl}^{-}$ & 13.00 \\
$\mathrm{SO}_{4}=$ & 13.60 \\
\hline
\end{tabular}


A pot experiments were carried out at the green house of the Faculty of Agriculture (Saba bacha), Alexandria University, Egypt during 2011 growing season using plastic pots. The pots were $30 \mathrm{~cm}$ deep and $13 \mathrm{~cm}$ in diameter with holes in their bottom, The pots were filled with $1 \mathrm{~kg}$ of air- dried soil leaving the upper $5 \mathrm{~cm}$ without soil. Seeds of tomato (Strain B) were planted in each pot. This experiment was designed as split - split plot with three replicates. The main plots were for irrigation water salinity types $(0.44,2.7,6.2$ and $12.5 \mathrm{dS} / \mathrm{m})$, the sub plots for compost rates $(0,20$ and $40 \mathrm{~g} / \mathrm{kg}$ soil) and the sub sub plots for mycorrhiza inoculation (without, Glomus intraradiaces (GC) and Glomus macrocarpium (GM)). About fifty grams of inoculum Glomus intraradiaces and $100 \mathrm{ml}$ of an inoculum suspension (involving spores and colonized root segments) for the other species Glomus macrocarpium, were placed $2 \mathrm{~cm}$ below the seeds.

Table (3). The chemical characteristic of saline irrigation water

\begin{tabular}{|l|c|c|c|}
\hline \multirow{2}{*}{ Paremeter } & \multicolumn{3}{c|}{ Water Salinity, (dS/m) } \\
\cline { 2 - 4 } & $\mathbf{2 . 7}$ & $\mathbf{6 . 2}$ & $\mathbf{1 2 . 5}$ \\
\hline $\mathrm{pH}$ & 8.08 & 8.18 & 8.89 \\
Water soluble cations, meq/L & & & \\
$\mathrm{Ca}^{2+}$ & 1.32 & 2.86 & 4.60 \\
$\mathrm{Mg}^{2+}$ & 2.3 & 4.60 & 8.10 \\
$\mathrm{Na}^{+}$ & 23.0 & 52.8 & 106.5 \\
$\mathrm{~K}^{+}$ & 0.83 & 1.91 & 3.85 \\
Water soluble anions, meq/L $^{*}$ & & & \\
$\mathrm{HCO}_{3}^{-}$ & 11.7 & 20.8 & 34.40 \\
$\mathrm{Cl}^{-}$ & 11.88 & 38.3 & 46.10 \\
$\mathrm{SO}_{4}{ }^{-}$ & 4.50 & 6.90 & 45.10 \\
\hline
\end{tabular}

Four seeds of Tomato were planted into each pot and after two weeks from emergence the plants were thinned to two plants. The experiment was carried out in a sunlight green-house with natural light, a day/night temperature $30{ }^{\circ} \mathrm{C} / 22{ }^{\circ} \mathrm{C}$, and a relative humidity $50-70 \%$. The soil of each pot was fertilized with $200 \mathrm{mg} \mathrm{N}$ $\mathrm{kg}^{-1}$ soil in the form of $\left(\mathrm{NH}_{2}\right)_{2} \mathrm{CO}(46 \% \mathrm{~N}), 410 \mathrm{mg} / \mathrm{kg}^{-1}$ soil in the form of $\mathrm{K}_{2} \mathrm{SO}_{4}$ $\left(48 \% \mathrm{~K}_{2} \mathrm{O}\right)$ and $200 \mathrm{mg} \mathrm{P}_{2} \mathrm{O}_{5} \mathrm{~kg}^{-1}$ soil $\left(15.5 \% \mathrm{P}_{2} \mathrm{O}_{5}\right)$ in the form of $\mathrm{Ca}\left(\mathrm{H}_{2} \mathrm{PO}_{4}\right)_{2}$. All pots were irrigated every day to keep the soil at $70 \%$ of its field capacity by regular weighing of pots. After 7 weeks of growth, shoot of plants were taken from each pot and washed with running tap water, and then with distilled water. The samples were air dried for few hours and then oven dried at $70{ }^{\circ} \mathrm{C}$ for 48 hours, grounded after recording the dry weight of the plant parts (shoot). After dryness, the plant samples were milled well and kept in plastic container for chemical analysis. Samples of the dried plant material $(0.5 \mathrm{~g})$ were wet-digested with $\mathrm{H}_{2} \mathrm{SO}_{4}-\mathrm{H}_{2} \mathrm{O}_{2}$ digest (Lowther, 1980) and the $\mathrm{P}, \mathrm{K}, \mathrm{Na}, \mathrm{Cu}, \mathrm{Zn}, \mathrm{Mn}$ and $\mathrm{Fe}$ were determined in the digested solution, according to Jackson (1973). Phosphorus was measured in the digested solution using vanado-molydate color reaction according to the 
method described by Jackson (1973). Potassium and sodium were measured in the digested suspension using flamephotometer. The micronutrients were determined by atomic absorption spectrophotometer. Also, nitrogen content was determined by micro-Kjeldahl method according to Bermner and Mulvaney, (1982). All data were subjected to analysis of variance or regression analysis according to Snedecor and Cochran (1972) and L.S.D test at 0.05 level of probability was used to compare between means.

\section{RESULTS AND DISCUSION}

The obtained results in (Table 4). revealed that the average shoot dry weight of tomato plant due to compost and AMF inoculation was significantly decreased gradually by increasing salinity of irrigation water. The significance of soil salinity on agricultural yield is enormous as stated by Tester and Davenport (2003). The salinity generally affects the establishment growth and development of plants leading to losses in productivity (Mathur et al., 2007). This effect was pronounced in plants grown under higher salinity levels of irrigation water ( 6.2 and $12.5 \mathrm{dS} / \mathrm{m}$ ) as compared with the control.

Table (4). Mean effects of irrigation water salinity, compost rate and mycorrhiza incoluation on shoot dry weight of tomato plant

\begin{tabular}{c|c}
\hline \multirow{2}{*}{ Treatments } & Dry weight, (g/pot) \\
\hline \multicolumn{3}{c}{ Salinity levels, dS/m } \\
\hline 0.44 & 5.01 \\
2.70 & 4.60 \\
6.20 & 4.41 \\
12.50 & 4.13 \\
\hline LSD $_{0.05}$ & 0.037 \\
\hline \multicolumn{2}{c}{ Compost rate, g/kg soil } \\
20 & 4.31 \\
40 & 4.57 \\
\hline LSD0.05 & 4.74 \\
\hline \multicolumn{2}{|c}{ Mycorrhiza inoculation } \\
\hline Without & 3.022 \\
GC & 4.77 \\
GM & 4.98 \\
\hline LSD $_{0.05}$ & 0.033 \\
\hline
\end{tabular}

Vol. 20(1), 2015 
The direct effects of salts on plant growth may involve: (a) reduction in the osmotic potential of the soil solution that reduces the amount of water available to the plant causing physiological drought (Feng et al., 2002; Jahromi et al., 2008); (b) toxicity of excessive $\mathrm{Na}$ and $\mathrm{Cl}$ ions towards the cell (Feng et al., 2002); and (c) nutrient imbalance in the plant caused by nutrient uptake and/or transport to the shoot leading to ion deficiencies (Adiku et al. 2001). Gunies et al.(1996) reported that under saline conditions, the plants failed to maintain the required balance of organic and inorganic constituents leading to suppress the plant growth. This result is in line with those obtained by Ahmed et al., (2001) on Ambrosia maritime, Arshi et al. (2002) on senna plants, Shalan et al. (2006) on Majarana hortensis, L. and Abdel-Mawgoud et al. (2010) on green bean plants.

To deal with irrigation by saline water and minimize crop loss, scientists have searched for incorporating or applying factors that enable plants to better withstand salt stress such as compost application and or AMF inoculation which could help to improve crop production under saline conditions.

Data concerning the effect of compost application rates showed that, the highest significant values of shoot dry weight of tomato plant produce from $40 \mathrm{~g}$ compost $/ \mathrm{kg}$ soil. The shoot dry weight of tomato plants gradually increased by increasing compost rate (Table 5). It has been demonstrated that the application of compost to soil improves some physical properties such as porosity, water-holding capacity and bulk density. It also promotes buffering capacity of the soil and increases the percentage of organic matter and cation exchange capacity (Soheil et al., 2012). Likewise, the organic composts improve soil health and nutrient status (Pandey and Shukla, 2006). Varindepal et al., (2006) reported that, incorporation of organic compost decreased $\mathrm{P}$ adsorption, maximum buffering capacity, bonding energy, and increased $\mathrm{P}$ concentration in solution. Kavvadias et al. (2011) reported that organic matter application to soil can lead to some beneficial soil chemical and physical characteristics, such as increases in organic matter, organic carbon, major nutrients (e.g N, K), water-holding capacity and porosity. The obtained results are in line of those obtained by Vendrame et al.(2005) on some ornamental plant and Atif et al.(2008) on zinnia elegans. 
Table (5). The interaction effect between irrigation water salinity (S) and compost rate ( $\mathrm{C}$ ) on shoot dry weight of tomato plants

\begin{tabular}{|c|c|c|}
\hline \multirow{2}{*}{ Irrigation water salinity, $\mathbf{d S} / \mathbf{m}$} & Compost rate $\mathbf{( g / k g}$ soil) & Dry weight $\mathbf{( g / p o t}$ ) \\
\hline \multirow{3}{*}{0.44} & 0 & 4.579 \\
\cline { 2 - 3 } & 20 & 5.089 \\
\cline { 2 - 3 } & 40 & 5.361 \\
\hline \multirow{3}{*}{2.7} & 0 & 4.167 \\
\cline { 2 - 3 } & 20 & 4.707 \\
\cline { 2 - 3 } & 40 & 4.928 \\
\hline \multirow{3}{*}{6.2} & 0 & 4.433 \\
\cline { 2 - 3 } & 20 & 4.348 \\
\cline { 2 - 3 } & 40 & 4.440 \\
\hline \multirow{2}{*}{12.5} & 0 & 4.045 \\
\cline { 2 - 3 } & 20 & 4.119 \\
\cline { 2 - 3 } & 40 & 0.092 \\
\hline
\end{tabular}

The application of organic matter to saline soils or soil irrigated with saline waters can have different effects such as speeding up of $\mathrm{NaCl}$ leaching, decrease of the exchangeable sodium percentage and electrical conductivity and increase of water infiltration (El-Shakweer, et al., 1998). The beneficial effect of OM have been attributed to release root exudates such as organic acids which regulate soil $\mathrm{pH}$ and decrease the harmful effect of increasing salt concentration of soil and to improve soil physical properties and nutrient availability (Deluca and Deluca 1987).

The second approach is the inoculation with arbuscular mycorrhizal fungi. The results in Table 6 indicated that, the inoculation of AM fungi caused in significant increase in shoot dry weight per pot when compared to the uninoculated plants at all levels of irrigation water salinity and and compost rates. The Glomus macrocarpium was more effective than Glomus intraradiaces. Mycorrhizal colonization is common in tomato plants and well documented a mycotrophic plant (Kubota et al., 2005). Many studies were conducted to assess the response of tomato seedlings with the inoculation of AMF. The inoculated seedlings showed better performance due to its higher shoot fresh weight (Oseni et al., 2010). Arbuscular mycorrhizal fungi promote salinity tolerance by employing various mechanisms, such as enhancing nutrient acquisition (Al-Karaki and Al-Raddad, 1997), producing plant growth hormones, improving rhizospheric and soil conditions (Lindermann, 1994), altering the physiological and biochemical properties of the host (Smith and Read, 1995) and defending roots against soilborne pathogens (Dehne, 1982). In addition, AMF can improve host physiological processes like water absorption capacity of plants by increasing root hydraulic conductivity and favourably adjusting the osmotic balance and composition of carbohydrates (Ruiz -Lozano, 2003). 
With regard to the interaction between salinity of irrigation water and compost rate, data presented in Table (5) revealed that compost rates under salinity stress significantly increased shoot dry weight of tomato plant compared to that without compost. The interaction between irrigation water salinity and mycorrhizal inoculation (SxM) had a significant effect on shoot dry weight, (Table 6). The highest value of shoot dry weight was obtained through $0.44 \mathrm{dS} / \mathrm{m}$ irrigation water with GM inoculation, while the lowest value was obtained with $12.5 \mathrm{dS} / \mathrm{m}$ irrigation water salinity without AMF inoculation. The interaction between compost rate and mycorrhizal inoculation (CxM) had highly significant effect on dry weight (Table 7). The highest value of shoot dry weight was obtained due to applying $40 \mathrm{~g}$ compost per kg soil with Glomus macrocarpiu.

The second-order interaction between irrigation water salinity, compost rate and mycorrhizal inoculation ( $\mathrm{S} \times \mathrm{C} \times \mathrm{M}$ ) had significant effect on shoot dry weight (Fig 1). The highest value of dry weight was obtained from $0.44 \mathrm{dS} / \mathrm{m}$ irrigation water salinity, $40 \mathrm{~g}$ compost/kg soil and Glomus macrocarpium.

The dry weight of tomato shoot $(Y)$ without mycorrhizal inoculation was regressed against the irrigation water salinity $\left(X_{1}\right)$, and compost rate $\left(X_{2}\right)$. The regression equation for the relationship was:

$$
\begin{array}{cc}
Y=3.961-0.071 X_{1}+0.010 X_{2} \\
R^{2}=0.868^{* *} & P<0.01
\end{array}
$$

The comparison of the slopes of each variable in the equation $(0.071: 0.01)$ gives a quantitative estimate for the efficiency of one variable to the other. Thus the efficiency of salinity irrigation water and compost rate would be equal to (1: 0.141$)$. The dry weight of tomato shoot (Y) With Glomus macrocarpium inoculation was also regressed with the two variables. The regression equation for the relationship was:

Table (6).The interaction effect between irrigation water salinity (S) and Mycorrhiza inculation (M) on shoot dry weight of tomato plants

\begin{tabular}{|c|c|c|}
\hline Irrigation water salinity, dS/m & Mycorrhiza oculation & Dry weight (g/pot) \\
\hline \multirow{3}{*}{0.44} & Without & 4.233 \\
\cline { 2 - 3 } & GC & 5.325 \\
\cline { 2 - 3 } & GM & 5.470 \\
\hline \multirow{3}{*}{2.7} & Without & 3.827 \\
\cline { 2 - 3 } & GC & 4.963 \\
\cline { 2 - 3 } & GM & 5.011 \\
\hline \multirow{3}{*}{6.2} & Without & 3.435 \\
\cline { 2 - 3 } & GC & 4.617 \\
\cline { 2 - 3 } & GM & 4.836 \\
\hline \multirow{2}{*}{12.5} & Without & 3.265 \\
\cline { 2 - 3 } & GC & 4.531 \\
\cline { 2 - 3 } & GM & 4.606 \\
\hline
\end{tabular}

Vol. 20(1), 2015 


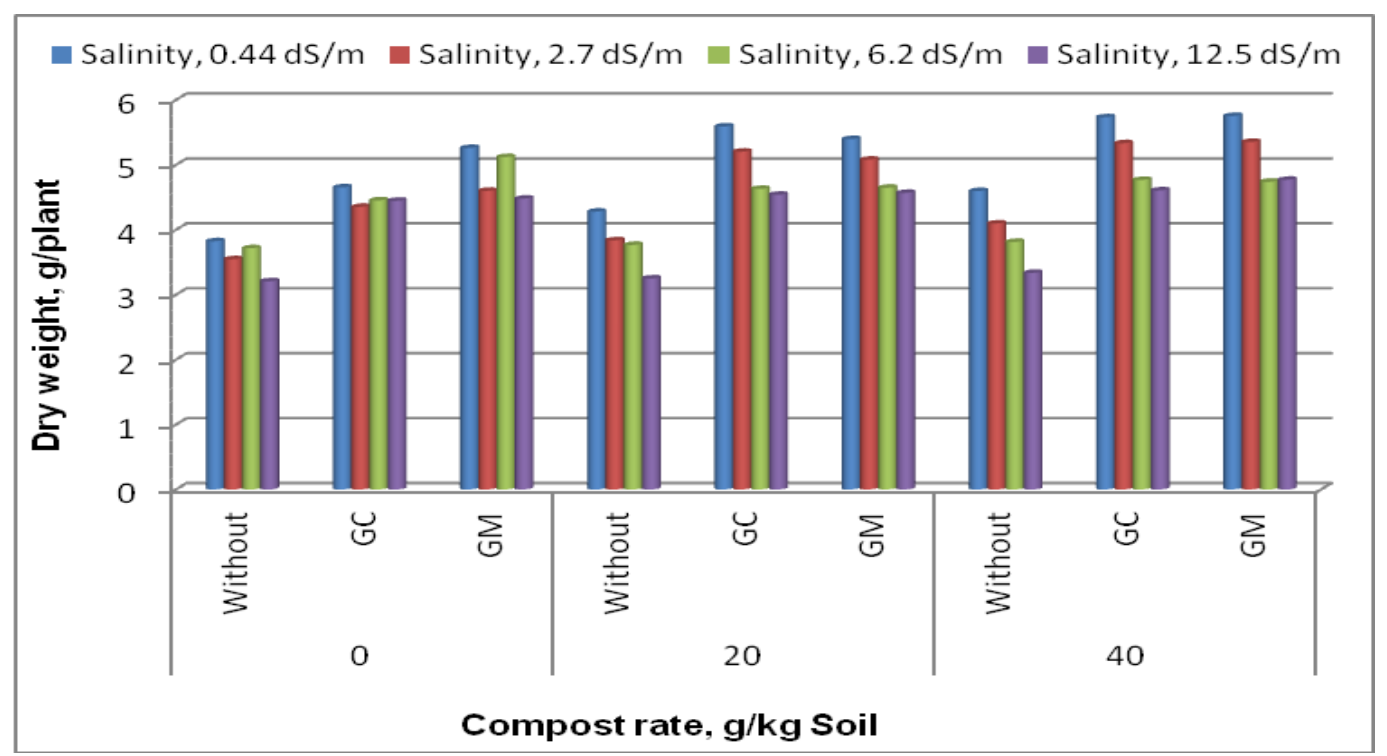

Fig ( 1 ): The effect of irrigation water salinity, compost rate and mycorrhizal inoculation on dry weight of shoot tomato plant

Table (7). The interaction effect between compost rate (C) and Mycorrhiza inculation (M) on shoot dry weight of tomato plants

\begin{tabular}{|c|c|c|}
\hline \multirow{2}{*}{ Compost rates,g/kg soil } & Mycorrhiza inoculation & Dry weight (g/pot) \\
\hline \multirow{3}{*}{0} & Without & 3.574 \\
\cline { 2 - 3 } & GC & 4,477 \\
\cline { 2 - 3 } & GM & 4.865 \\
\hline \multirow{2}{*}{20} & Without & 3.780 \\
\cline { 2 - 3 } & GC & 4.991 \\
\cline { 2 - 3 } & GM & 4.923 \\
\hline \multirow{2}{*}{40} & Without & 3.961 \\
\cline { 2 - 3 } & GC & 5.110 \\
\cline { 2 - 3 } & GM & 5.154 \\
\hline
\end{tabular}

the dry weight of tomato shoot $(\mathrm{Y})$ with Glomus intraradiaces inoculation was regressed with salinity irrigation water $\left(X_{1}\right)$ and compost rates $\left(X_{2}\right)$ and the regression equation for the relationship was:

$$
\begin{array}{cc}
Y=4.868-0.061 & X_{1}+0.016 X_{2} \\
R^{2}=0.709 & P<0.01
\end{array}
$$

Thus the efficiency of irrigation water salinity: compost rate would be equal to 0.061: 0.016 or 1: 0.262 . These analyses indicated that dry weight of tomato shoot was strongly affected by both variables especially by irrigation water salinity. 
The effects of compost rate and mycorrhizal inoculation in relation to irrigation water salinity on elemental composition of tomato plant are presented in Tables (8, 10). The results in Table (8) represent the mean values of $\mathrm{N}, \mathrm{P}, \mathrm{K}$, and $\mathrm{Na}$ contents. In the same table, the N, P contents of shoot tomato plants were significantly increased as salinity increased from 0.44 to $6.2 \mathrm{dS} / \mathrm{m}$. In Table the same Table, $\mathrm{Na}$ ion content was significantly increased with increasing the salinity of irrigation water from 0.44 to $12.5 \mathrm{dS} / \mathrm{m}$. On the other hand the $\mathrm{K}$ ion content decreased with increasing water salinity up to $12.5 \mathrm{dS} / \mathrm{m}$.

Gomea et al. (1996) reported an increase in Na concentration and decrease in $\mathrm{K}$ concentration in the leaves with increasing salinity. These results may be due to a possible antagonism between $\mathrm{K}$ and $\mathrm{Na}$. This antagonism could be due to the direct competition between $\mathrm{K}$ and $\mathrm{Na}$ at the sites of ion uptake at plasmalemma. Accordingly, the increase in $\mathrm{Na}$ concentration in plant with salinity may be a result of the ability of plant to use $\mathrm{Na}$ to maintain an adequate osmotic potential gradient between the plant tissues and external solution (Glenn, 1987).

Table (8). Mean effect of irrigation water salinity, compost rate and mycorrhiza incoluation on nitrogen, phosphours, potassium and sodium contents in shoot of tomato plant

\begin{tabular}{|c|c|c|c|c|}
\hline \multirow{2}{*}{ Treatments } & Nitrogen & Phosphorus & Potassium & Sodium \\
\hline \multicolumn{5}{|c|}{ Salinity levels, dS/m } \\
\hline \multicolumn{5}{|c|}{$\%$} \\
\hline 0.44 & 2.78 & 0.131 & 0.735 & 1.35 \\
2.70 & 3.00 & 0.151 & 0.717 & 1.46 \\
6.20 & 3.15 & 0.165 & 0.693 & 1.59 \\
12.50 & 2.92 & 0.164 & 0.653 & 1.70 \\
\hline LSD $_{0.05}$ & 0.105 & $8.98 \mathrm{E}-03$ & 0.014 & 0.040 \\
\hline \multicolumn{5}{|c|}{ Compost rate, g/kg soil } \\
\hline 20 & 2.75 & 0.141 & 0.684 & 1.42 \\
40 & 2.96 & 0.146 & 0.698 & 1.52 \\
\hline LSD0.05 & 3.17 & 0.171 & 0.717 & 1.64 \\
\hline \multicolumn{5}{|c|}{ Mycorrhiza inoculation } \\
\hline Without & 2.96 & 0.141 & N.S. & 0.039 \\
GC & 2.96 & 0.156 & 0.676 & 1.45 \\
GM & 2.97 & 0.162 & 0.633 & 1.57 \\
\hline LSD & N.S. & $5.31 \mathrm{E}-03$ & $9.72 \mathrm{E}-03$ & 0.040 \\
\hline
\end{tabular}

Regarding the effect of compost rate on N, P, k and Na contents of shoot of tomato plant in Table 8, the increment of these nutrients could be attributed to their availability in compost which increased with increasing compost rates. Also,

Vol. 20(1), 2015 55 
this may be due to the ability of organic matter in rendering soil nutrients more available and chelating of these elements. This helps to increase the respiration rate, metabolism and growth of plant that causing the plant required to more nutrients from soil and fertilizers. Similar results were obtained by Shehata (2001) and Ewais et al. (2005).

The present study showed also, an increase in the contents of $\mathrm{N}, \mathrm{P}, \mathrm{K}$, and $\mathrm{Na}$ in the shoot of mycorrhizal fungi inoculated plants than in the shoot of the uninoculated plants (Table 8). AM inoculated plants recorded higher contents of $\mathrm{N}$, $\mathrm{P}, \mathrm{K}$, and $\mathrm{Na}$ elements and this may be due to AM hyphae net work which is substantiated by the observed increase in nutrients content (Bolan et al., 1994). The interaction between salinity of irrigation water and mycorrhizal inoculation (SxM) had significant effect on $\mathrm{N}$ contents in shoot tomato plants (Table 9). The highest value of $\mathrm{N}$ content was obtained through $6.2 \mathrm{dS} / \mathrm{m}$ irrigation water salinity with Glomus macrocarpium, while the lowest value was obtained through 0.44 $\mathrm{dS} / \mathrm{m}$ irrigation water salinity without mycorrhizal inoculation.

Table (9).The interaction between irrigation water salinity (S) and ycorrhiza inculation (M) on nitrogen content (\%) in shoot of tomato plant.

\begin{tabular}{|c|c|c|}
\hline Irrigation water salinity dS/m & Mycorrhiza & $\mathbf{N} \%$ \\
\hline \multirow{3}{*}{0.44} & Without & 2.709 \\
\cline { 2 - 3 } & GC & 2.866 \\
\cline { 2 - 3 } & GM & 2.768 \\
\hline \multirow{2}{*}{2.7} & Without & 2.967 \\
\cline { 2 - 3 } & GC & 3.029 \\
\cline { 2 - 3 } & GM & 3.089 \\
\hline \multirow{2}{*}{6.2} & Without & 3.067 \\
\cline { 2 - 3 } & GC & 3.124 \\
\cline { 2 - 3 } & GM & 3.247 \\
\hline \multirow{2}{*}{12.5} & Without & 3.102 \\
\cline { 2 - 3 } & GC & 2.815 \\
\cline { 2 - 3 } & GM & 2.844 \\
\hline
\end{tabular}

Data in Table (10) revaled the average values of the micronutrients ( $\mathrm{Fe}, \mathrm{Zn}$, $\mathrm{Mn}$ and $\mathrm{Cu}$ ) contents in shoot of tomato plants as affected by irrigation water salinity, compost rates and mycorrhizal inoculation. It is clear that $\mathrm{Zn}, \mathrm{Mn}$ and $\mathrm{Cu}$ contents in shoots of tomato plants were significantly increased as salinity of irrigation water increased from 0.44 to $6.2 \mathrm{dS} / \mathrm{m}$. Table (10) showed also, the effect of compost rates on $\mathrm{Fe}, \mathrm{Zn}, \mathrm{Mn}$ and $\mathrm{Cu}$ in shoot of tomato plant. The results showed that there werehighly significance variations in $\mathrm{Zn}, \mathrm{Mn}$ and $\mathrm{Cu}$ contents. The highest values of $\mathrm{Fe}, \mathrm{Zn}, \mathrm{Mn}$ and $\mathrm{Cu}$ were produced with $40 \mathrm{~g}$ compost $/ \mathrm{kg}$ soil. Data in Table 10 showed that inoculation with AM fungi significantly increased $\mathrm{Fe}, \mathrm{Zn}, \mathrm{Mn}$ and $\mathrm{Cu}$ contentsin shoot of tomato plant as compared to the nonmycorrhizal tomato plants. The inoculation with Glomus macrocarpium was more effective than with Glomus intradiaces for $\mathrm{Zn}, \mathrm{Mn}$ and $\mathrm{Cu}$. 
The interaction between salinity of irrigation water and compost rate $(S \times C)$ had significant effect on $\mathrm{Zn}$ content in shoot tomato plants (Table 11). The highest value of $\mathrm{Zn}$ was obtained through $6.2 \mathrm{dS} / \mathrm{m}$ irrigation water salinity using $40 \mathrm{~g}$ compost / kg soil, while the lowest value of $\mathrm{Zn}$ was obtained through $0.44 \mathrm{dS} / \mathrm{m}$ irrigation water salinity without compost. Also, the interaction between compost rates and mycorrhizal inoculatin $(C \times M)$ significantly effectd $Z n$ and $M n$ contents in shoot of tomato plants (12). The highest values of $\mathrm{Zn}$ and $\mathrm{Mn}$ were obtained through $40 \mathrm{~g}$ compost $/ \mathrm{kg}$ soil with Glomus macrocarpium.

Salinity interferes with nitrogen $(\mathrm{N})$ acquisition and utilization by influencing different stages of $\mathrm{N}$ metabolism, such as $\mathrm{NO}_{3}$ ion uptake and reduction and protein synthesis (Frechill et al., 2001). Application of AMF can help in better assimilation of nitrogen in the host plant. Giri and Mukerji (2004) recorded higher accumulation of $\mathrm{N}$ in shoots of mycorrhizal Sesbania grandiflora and $\mathrm{S}$. aegyptiaca than in non-mycorrhizal control plants. The extra radical mycelia take up inorganic nitrogen from the soil in the form of nitrate and assimilated it via nitrate reductase, located in the arbuscule-containing cells (Kaldorf et al., 1998). Cliquet and Stewart (1993) observed increased of $\mathrm{N}$ uptake in an AMF inoculated plant due to a change in $\mathrm{N}$ metabolism brought about by changes in the enzymes associated with $\mathrm{N}$ metabolism (Mathur and Vyas, 1996). Severals studies have reported that improved $\mathrm{N}$ nutrition may help to reduce the toxic effects of $\mathrm{Na}$ ions by reducing its uptake and this may indirectly help in maintaining the chlorophyll content of the plant.

Table (10). Mean effect of irrigation water salinity, compost rate and mycorrhiza incoluation on iron, zinc, manganese and copper contents in shoot of tomato plants

\begin{tabular}{|c|c|c|c|c|}
\hline Treatments & Iron & Zinc & Manganese & Copper \\
\hline \multicolumn{5}{|c|}{ mg/kg D.W. } \\
\hline \multicolumn{5}{|c|}{ Salinity levels, dS/m } \\
\hline 0.44 & 270.04 & 89.48 & 40.89 & 49.44 \\
2.70 & 213.19 & 103.04 & 47.67 & 53.56 \\
6.20 & 228.78 & 113.74 & 53.33 & 58.44 \\
12.5 & 207.30 & 102.22 & 46.59 & 51.78 \\
\hline LSD $_{0.05}$ & N.S. & 1.868 & 2.278 & 0.655 \\
\hline \multicolumn{5}{|c|}{ Compost rate, g/kg soil } \\
\hline 0 & 245.69 & 94.81 & 41.97 & 50.56 \\
20 & 213.78 & 101.00 & 47.11 & 52.28 \\
40 & 230.00 & 110.56 & 52.28 & 57.08 \\
\hline LSD0.05 & N.S. & 1.465 & 1.65 & 0.659 \\
\hline \multicolumn{5}{|c|}{ Mycorrhiza inoculation } \\
\hline Without & 144.67 & 85.06 & 39.08 & 44.86 \\
GC & 295.14 & 105.83 & 46.67 & 54.69 \\
GM & 249.67 & 115.47 & 55.61 & 60.36 \\
\hline LSD $_{0.05}$ & 42.16 & 1.916 & 1.14 & 1.145 \\
\hline
\end{tabular}

Vol. 20(1), 2015 
When $\mathrm{Na}$ or salt concentration in the soil is high, plants tend to take up more $\mathrm{Na}$ resulting in decreased $\mathrm{K}$ uptake. $\mathrm{Na}$ ions compete with $\mathrm{K}$ for binding sites essential for various cellular functions. Potassium plays a key role in plant metabolism. It activates a range of enzymes, and plays an important role in stomatal movements and protein synthesis. High concentrations of $\mathrm{K}$ are required in protein synthesis as is used in the binding of tRNA to the ribosomes (Blaha et al., 2000). These functions cannot be replaced by Na ions (Giri et al., 2007).

Mycorrhizal colonization can enhance $\mathrm{K}$ absorption under saline conditions (Giri et al., 2007; Zuccarini and Okurowska, 2008) while, it can decrease Na translocation to shoot tissues. Na uptake may also be influenced by the synthesis and storage of polyphosphate (Olrovich and Ashford, 1993) as well as by other cations, particularly K (Giri et al., 2003).

Arbuscular mycorrhizal fungi also improve micronutrient acquisition by increasing the surface area of soil explored by mycorrhizal roots and increasing the solubility of metals by producing metal-chelators (Szaniszlo et al. 1981). AMF improves the absorption of copper (Gildon and Tinker, 1983), zinc (Faber et al., 1990; Gildon and Tinker, 1983) and iron (Al-Karaki, 2006).

Table(11).The interaction effect between irrigation water salinity(S) and compost rate $(\mathrm{C})$ on Zinc content in shoot of tomato plants

\begin{tabular}{|c|c|c|}
\hline Irrigation water salinity, dS/m & $\begin{array}{c}\text { Compost rate } \\
\text { (g/kg soil) }\end{array}$ & $\begin{array}{c}\text { Zn } \\
\text { (mg/kg D.w.) }\end{array}$ \\
\hline \multirow{3}{*}{0.44} & 0 & 80.33 \\
\hline & 20 & 84.67 \\
\hline & 40 & 103.45 \\
\hline \multirow{3}{*}{2.7} & 0 & 93.67 \\
\hline & 20 & 102.00 \\
\hline & 40 & 113.45 \\
\hline \multirow{3}{*}{6.2} & 0 & 105.67 \\
\hline & 20 & 113.78 \\
\hline & 40 & 121.78 \\
\hline \multirow{3}{*}{12.5} & 0 & 99.56 \\
\hline & 20 & 104.22 \\
\hline & 40 & 103.56 \\
\hline \multicolumn{2}{|l|}{$\mathrm{LSD}_{0.05}$} & 6.214 \\
\hline
\end{tabular}


Table (12). The interaction effect between compost rate ( $C$ ) and Mycorrhiza inculation (M) on zinc and manganese contents in shoot of tomato plants

\begin{tabular}{|c|c|c|c|}
\hline $\begin{array}{c}\text { Compost rates, } \\
\text { g/kg soil }\end{array}$ & Mycorrhiza & $\begin{array}{c}\mathrm{Zn} \\
(\mathrm{mg} / \mathrm{kg} \text { D.w) }\end{array}$ & $\begin{array}{c}\text { Mn } \\
\text { (mg/kg D.w.) }\end{array}$ \\
\hline \multirow[t]{3}{*}{-0} & Without & 81.75 & 33.00 \\
\hline & GC & 94.08 & 39.16 \\
\hline & GM & 108.58 & 53.75 \\
\hline \multirow{3}{*}{20} & Without & 84.92 & 40.42 \\
\hline & GC & 106.33 & 46.17 \\
\hline & GM & 111.75 & 54.75 \\
\hline \multirow{3}{*}{40} & Without & 88.50 & 43.83 \\
\hline & GC & 117.08 & 54.67 \\
\hline & GM & 126.08 & 58.33 \\
\hline \multicolumn{2}{|c|}{$\mathrm{LSD}_{0.05}$} & 6.671 & 3.983 \\
\hline
\end{tabular}

CONCLUSION: The AM fungal represented by Glomus macrocarpium or Glomus intraradiaces with compost application can benefit against potentially salt stress conditions. The Glomus macrocarpium was more effective, in general, than Glomus intraradiaces. These is further confirmation that compost application and mycorrhizal symbiosis are especially beneficial for plant growth under soil salinity stress. Thus it is needed to develop more exact tests through more exploratory experiments on several tomato cultivares and AMF species to drive more pruise results when we irrigate with saline waters.

\section{REFRENCES:}

Abdel Latef, A.A.H. and H.E. Chaoxing (2011). Effect of arbuscular mycorrhizal fungi on growth, mineral nutrition, antioxidant enzymes activity and fruit yield of tomato grown under salinity stress. Sci. Hort., 127: 228-233.

Abdel-Mawgoud, A.M.R., M.A. El-Nemr, A.S.Tantawy and Hoda A. Habib (2010). Alleviation of salinity effects on green ben plants using some environmental friendly materials.J. App. Sci. Res., 6 (7): 871-878.

Adiku, G., M.Renger , G. Wessolek , M. Facklam and C. Hech-Bischoltz (2001) . Simulation of dry matter production and seed yield of common beans under varying soil water and salinity conditions. Agri. Water Manag.,47:55-68.

Adler, P.R. and G.E. Wilcor (1987). Salt stress, mechanical stress, or Chloromequat chloride effects on morphology and growth recovery of hydroponic tomato transplants. J. Amer. Hort. Sci., 112: 22-25.

Ahmed, S.H.K., A.F. Ali and M.R. Khater (2001). Effect of salinity treatments and active dry yeast on groeth and active ingredients of Ambrosia maritime, L. The Fifth Arabian Hort. Conf. Ismailia. Egypt, pp: 127-224.

Aliasgharzadeh, N., N. Rastin, H. Towfighi and A. Alizadeh (2001). Occurrence of arbuscular mycorrhizal fungi in saline soils of the Tabriz Plain of Iran in relation to some physical and chemical properties of soil. Mycorrhiza, 11:119-122. 
Al-Karaki, G. N. and A. Al-Raddad (1997). Effect of arbuscular mycorrhizal fungi and drought stress on growth and nutrient uptake of two wheat genotypes differing in drought resistance. Mycorrhiza.7:83-88.

Al-Karaki, G.N. (2006). Nursery inoculation of tomato with arbuscular mycorrhizal fungi and subsequent performance under irrigation with saline water. Sci. Hort., 109:1-7.

Arshi, A., M.Z. Abdin and M. Iqbal (2002). Growth metabolism on senna plants as affected by salt stress.Biologie Plant Arum., 45 (2): 295-298.

Atif, R., M. Arshad, A. Younis, A. Raza and M. Hameed (2008). Effects of different growing media on growth and flowering of Zinnia elegans cv. Blue Point. Pak. J. Bot., 40 (4): 1579-1585.

Bermner, J.M. and C.S. Mulvaney (1982). Total nitrogen, PP. 595-624. In A.L. Page, et al., (ed.). Methods of Soil Analysis. Part 2. Book Series No. 9. Am. Soc. of Agron. and Soil Sci., Soc. Am. Madison, Wisconsin, U.S.A.

Blaha, G., U. Stelzl , C.M.T. Spahn, R.K. Agrawal, J. Frank and K.H. Nierhaus (2000). Preparation of functional ribosomal complexes and effect of buffer conditions on tRNA positions observed by cryoelectron microscopy. Methods in Enzymology, 317:292-309.

Bolan, N.S., R. Naidu, S. Mahimairaja and S. Baskaran (1994). Influence of low molecular weight organic acids on the solublization of phosphates. Biol. Fert. Soils., 18: 311-319.

Cliquet, J.B. and G.R. Stewart (1993). Ammonia assimilation in Zea mays L. infected with a vesicular arbuscular mycorrhizal fungus Glomus fasciculatum. Plant Phys., 101:865-871.

Cuartero, J. and Fernandez-Munoz (1999). Effects of salinity on tomato. Sci. Hort. 78:83-125.

Dehne, H.W. (1982). Interaction between vesicular-arbuscular mycorrhizal fungi and plant pathogens. Phytopathology., 72:1115-1119.

Deluca, T,H. and D.K. Deluca (1987). Coposting for feedlot management and soil quality.J.Prod. Agric., 10:236-241.

El-Shakweer, M.H.A., E.A. El-Sayad and M.S.A. Ejes (1998). Soil and plant analysis as a guide for interpretation of the improvement efficiency of organic conditioners added to different soils in Egypt. Commu. Soil Sci. \& Plant ., 29: (11-14), 2067-2088.

Ewais, M. A., A. M. Abd El-Latif, A., A. Mohamoud and M.M. Abd El-Ghani (2005). Integrated effect of organic and inorganic fertilizers on growth, yield and NPK uptake by onion plants grown on a sand soil. Egypt J. Appl. Sci., 20 (10 A): 702-716.

Faber, B., A. Robert, J. Zasoski, R. G. Burau and K. Uriu. (1990). Zinc uptake by corn as affected by vesicular-arbuscular mycorrhizae. Plant and Soil. 129: 121-130.

Feng, G., F.S. Zhang, C.Y. Li XI, T. C. Tang and Z. Rengel (2002). Improved tolerance of maize plants to salt stress by arbuscular mycorrhiza is related to higher accumulation of soluble sugars in roots. Mycorrhiza., 12:185-190.

Vol. 20(1), 2015 
Frechill S., B. Lasa, L. Ibarretxe, C. Lamsfus and P. Aparicio Trejo (2001). Pea response to saline stress is affected by the source of nitrogen nutrition (ammonium or nitrate). Plant Growth Regulators, 35:171-179.

Gallagher J.K. (1985). Halophytic crops for cultivation at seawater salinity. Plant and Soil. 89:323-336.

Gerdemann, J. W. and T.H. Nicolson, (1963). Spores of mycorrhizal Endogene species extracted from soil by wet sieving. Trans. Brit. Mycol Soc., 46: 234235.

Ghassemi F., A.J. jakeman and H.A. Nix (1995). Salinization of land and water resources. Human Causes, extent, Management and case Studies, university of New South Wales.

Gildon, A., and P.B. Tinker (1983). Interactions of vesicular-arbuscular mycorrhizal infection and heavy metals in plants. II. The effects of heavy metals on the development of vesicular-arbuscular mycorrhizas. New Phytologist., 95, 247-261.

Giri, B. and K.G. Mukerji (2004). Mycorrhizal inoculant alleviates salt stress in Sesbania aegyptiaca and Sesbania grandiflora under field conditions: evidence for reduced sodium and improved magnesium uptake. Mycorrhiza, 14:307-312.

Giri, B., R. Kapoor and K.G. Mukerji (2003). Influence of arbuscular mycorrhizal fungi and salinity on growth, biomass and mineral nutrition of Acacia auriculiformis. Biology and Fertility of Soils, 38:170-175.

Giri, B., R. Kapoor and K.G. Mukerji (2007). Improved tolerance of Acacia nilotica to salt stress by arbuscular mycorrhiza, Glomus fasciculatum, may be partly related to elevated $\mathrm{K}^{+} / \mathrm{Na}^{+}$ratios in root and shoot tissues. Microbial Ecology 54:753-760.

Glenn, E.P. (1987). Relationship between cation accumulation and water content of salt tolerant grasses and sledge. Plant Cell Environ., 10: 205-212.

Gomea, I., J. Navarro, R. Moral, M. Iborra, G. Palacios and J.Mataix (1996). Salinity and nitrogen fertilization affecting the macronutrient content and yield of sweet pepper plants.J. Plant Nutr., 19:353-359.

Gunies, A., A. Inal and M.A. L Paslan(1996). Effect of salinity on stomatal resistance, proline and mineral composition of pepper. J. Plant Nutr., 19 (2): 389-396.

Herenica, J.F., J.C. Ruiz-Porras, S. Melero, P.A. Garcia-Galavis, E. Morillo and C. Maqueda (2007). Comparison between organic and mineral fertilization on soil fertility levels, crop macronutrient concentrations, and yield. Agro. J. 99: 973-983.

Jackson, M. L. (1973)."Soil Chemical Analysis". Printica Hall Private Ltd, New Delhi, India.

Jahromi, F., R. Aroca, R. Porcel and J.M. Ruiz-Lozano (2008). Influence of salinity on the in vitro development of Glomus intraradices and on the in vivo physiological and molecular responses of mycorrhizal lettuce plants. Microb.Eco, 55:45-53. 
Juniper, S.A.B. and L.K. Bott (1993). Vesicular-arbuscular mycorrhizas and soil salinity. Mycorrhiza, 4:45-57.

Kaldorf, M., E. Schemelzer and H. Bothe (1998). Expression of maize and fungal nitrate reductase in arbuscular mycorhiza. Molecular Plant-Microbe Interactions, 11:439-448.

Kavvadias, V., M. Papadopoulou, M. Doula and S. Theocharopoulos (2011). Olive mill waste application on soil: effect on soil microbial activity and its relation to soil chemical properties. $3^{\text {rd }}$ International Conference on Industrial and Hazadous Waste Mangement.

Kubota, M., T.P. Mcgonigle and M. Hyakumachi (2005). Arumand paris-type morphologies of arbuscular mycorrhizae in cucumber and tomato mycorrhiza, 15: 73-77.

Lindermann, R.G. (1994). Role of VAM in biocontrol. In: Pfleger FL, Linderman $R G$, editors. Mycorrhizae and plant health. St. Paul: American Phytopathological Society, 1-26.

Lowther, J. R. (1980). Use of a single sulfuric acid-hydrogen peroxide digest for the analysis of Pinus radiata needles. Commun .Soil Sci .Plant Anal., $11: 175-188$.

Mathur, N. and A. Vyas (1996). Biochemical changes in Ziziphus xyloropus by VA mycorrhizae. Botanical Bulletin of Academia Sinica., 37:209-212.

Mathur N, J. Singh, S. Bohra and A. Vyas (2007). Arbuscular mycorrhizal status of medicinal halophytes in saline areas of Indian Thar Desert. International Journal of Soil Science.,2:119-127.

Olrovich D.A. and A.E. Ashford (1993). Polyphosphate granules are artifact of specimen preparation in the ectomycorrhizal fungus Pisolithus tinctorius. Protoplasma. 173:91-102.

Omar M.A., F.A. Omar and S.M. Samarrai (1982). Effect of different soil treatments on tomato plants grown in Wadi Fatima soil. B. Effect of salinity treatments. Technical Report, Faculty of Meteorol. Enivron and Arid Land Agric. P. 26.

Oseni, T.O., N.S. Shongwe and M. T. Masarirambi (2010). Effect of arbuscular mycorrhiza (am) inoculation on the performance of tomato nursery seedings in vermiculite. Int. j. Agric. Biol., 12:789-792.

Page A. L., R. H. Miller, and D. R. Keeny (1982). Methods of Soil Analysis (Part 2). American Society of Agronomy, Madison, Wisconsin, USA.

Pandey, A.K. and P.K. Shukla (2006). Conservation and sustainable utilization of medicinal plants through people's participation and benefit sharing. J. Trop. Forestry, 22: 1-7.

Poss J.A., E.C. Pond, J.A. Menge and W.M. Jarrell (1985). Effect of salinity on mycorrhizal onion and tomato in soil with and without additional phosphate. Plant and Soil., 88:307-319.

Ruiz-Lozano, J.M. (2003). Arbuscular mycorrhizal symbiosis and alleviation of osmotic stress: new perspectives for molecular studies. Mycorrhiza., 13:309-317. 
Shalan, M.N., T.A.T. Abdel Latif and E.A.E. El-Ghadban (2006). Effect of water salinity and some nutritional compounds on the growth and production of sweet marjoram plants (Majorana hortensis L.) Egypt. J. Agric. Res., 84 (3): 959-975.

Shehata, S.M. (2001). Effect of some organic wastes application on growth, chemical contents and yield of squash plant. J. Agric. Sci. Mansoura Univ., 26 (9): 5695-5704.

Sheng, M., M. Tang, H. Chan, B. Yang, F. Zhang and Y. Huang (2008). Influence of arbuscular mycorrhizae on photosynthesis and water status of maize plants under salt stress. Mycorrhiza., 18:287-296.

Singh, S. A., H. D.Singh, N. Robbarts, , T. C. Bora, and N. R. Singh (2011). Comparative Study of Chemical Properties of Soibum- a Traditional Fermented Bamboo Shoot Product and Its Biological Investigation. Int. J. Biosci., Biochem and Bioinfo., 1 (2): 114-118.

Smith, S.E. and D.J. Read (1995). Mycorrhizal symbiosis. New York, NY: Academic Press. pp. 105-160.

Snedecor, W. and W. G. Cochran (1972). Statistical Method. $6^{\text {th }}$ Edition. The lowa State College Press. lowa, U.S.A.

Soheil, R., M.H. Hossien, S. Gholamreza, H. Leila, J. Mozhdeh and E. Hassan (2012). Effects of composted municipal waste and its leachate on some soil chemical propertie and corn plant responses.Inter. J. Agric. Res. Rev., 2 (6): 801-814.

Szaniszlo, P., E. Powell, R. Reid and G. Cline (1981). Production of hydroxamatesiderophore iron chelators by ectomycorrhizal fungi. Mycologia, 73: 1158-1174

Tester, M. and R. Davenport (2003). $\mathrm{Na}^{+}$tolerance and $\mathrm{Na}^{+}$transport in higher plants. Ann. Bot., 91:503-527.

Varindpal-singh, N.S. Dhillon and B.S. Brar (2006). Effect of incorporation of crop residues and organic manures on adsorption/ desorption and bioavaliability of phosphate. Nutr. Cycl. Agroecosyst.,76:95-108.

Vendrame, A.W., I. Magurie and K.K. Moore (2005). Growth of selected bedding plnts as affected by different compost percentages. Proc. Fla. State Hort. Soc., 118: 368-371.

Zuccarini, P. and P. Okurowska (2008). Effects of mycorrhizal colonization and fertilization on growth and photosynthesis of sweet basil under salt stress. J. Plant Nutr. $31(3): 497-513$. 


\section{الملخص العزبي}

استجابة الطماطم للتلقيح بفطر الميكوريزا وإضافة الكمبوست تحث حالة الإجهاد الملحي محمد مصباح التومي - ماهر جورجي نسيم - ماجدة أبوالمجد حسين - اسلام إبراهيم أبوالسعود

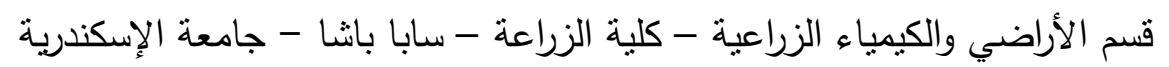

تم اجراء تجربة اصص بأستخدام تربة جيرية لدراسة تأثير الري بمياه ملحية محضرة بتخفيف مياه البحر علي نباتات الطماطم (سلالة B) الملقحة بالميكوريزا مع إضافة الكمبوست خلال الموسم الصيفي 2011.

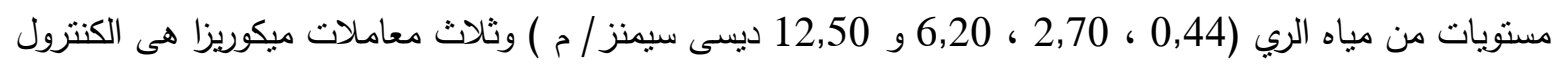

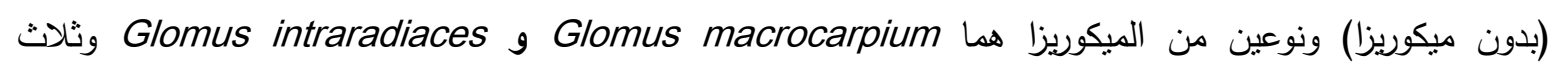

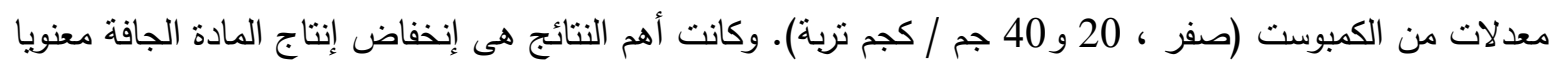

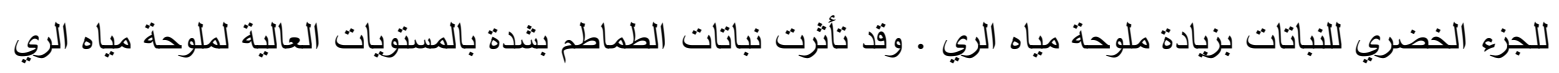

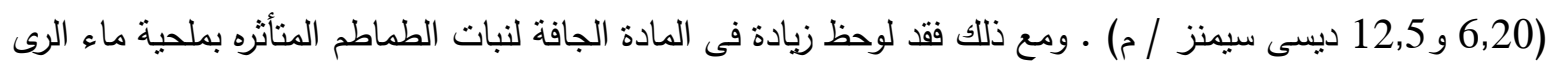

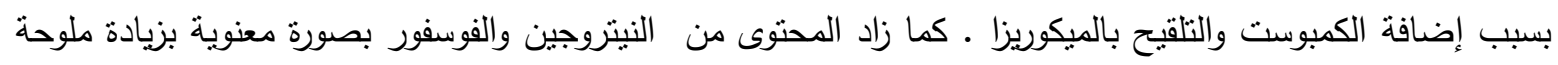

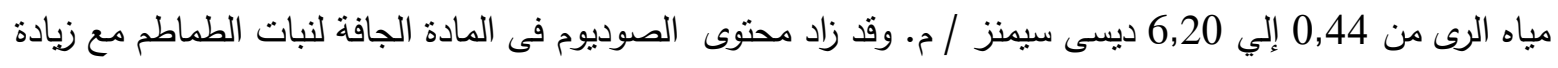

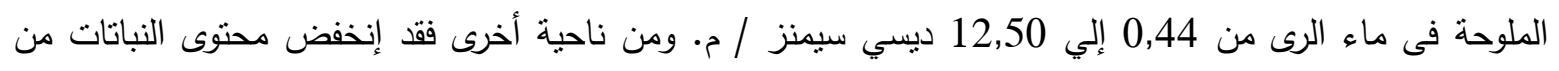

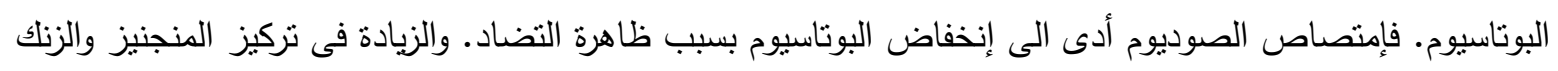

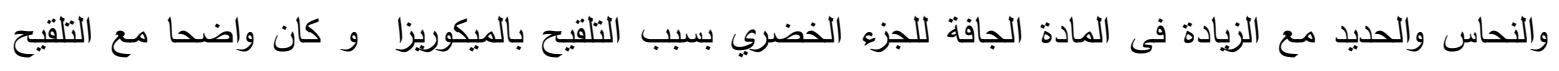

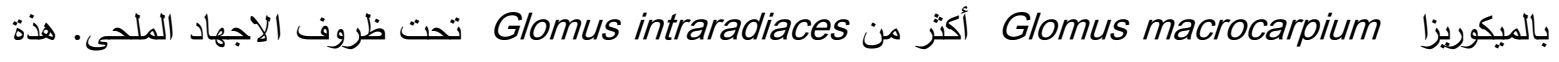

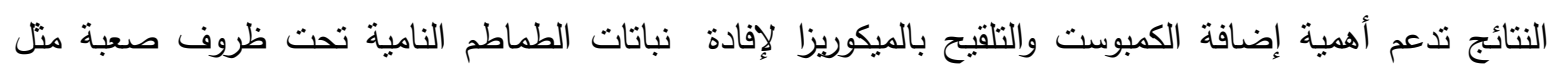

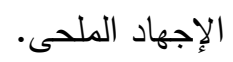


